\section{Олексій ПЛОТНІКОВ}

\section{Правосуддя перехідного періоду в Україні та біженці}

Тези присвячені правовому аналізу такого поняття, як правосуддя перехідного періоду в Україні, а також його вплив на біженців. У тезах визначено причини появлення значної кількості біженців в України, більшість 3 яких використовують Україну як транзитну територію до країн СС. У тезах також наведено випадок, коли особа може бути одночасно і біженцем, $\mathrm{i}$ внутрішньо переміщеною особою.

Ключові слова: правосуддя перехідного періоду, транзитивна юстиція, біженці, внутрішньо-переміщені особи, збройний конфлікт.

The concept of transitional justice has gained widespread recognition in Ukraine after the start of Russia's armed aggression in 2014. Non-governmental organizations raise questions about refugees in the transitional justice dimension. However, this issue does not need to be mentioned individually, but rather a complex scientific study in order to further consider the development and implementation of a transitional justice strategy in Ukraine.

Keywords: transitional justice, transitive justice, refugees, internally displaced persons, armed conflict.

Концепція правосуддя перехідного періоду ${ }^{1}$ набула широкого визнання в Україні після початку збройної агресії Російської Федерації в 2014 році. Після проведеної в травні 2017 році міжнародної наукової конференції «Пост-конфліктне правосуддя в Україні», можна говорити про консенсус серед дослідників та практиків щодо необхідності впровадження в Україні перехідного правосуддя. Наукова дискусія триває виключно щодо його обсягу та форм.

Як відомо, правосуддя перехідного періоду застосовується в конфліктних і постконфліктних ситуаціях. Такі ситуації пов'язані з насильством й грубими порушеннями прав людини. Природним наслідком таких ситуацій стає поява великої кількості осіб, які шукають порятунку від конфлікту чи ситуації насильства поза місцевістю свого постійного мешкання в своїй державі, або поза межами своєї держави. Ці особи можуть отримувати захист або від своєї держави (тоді вони стають внутрішньо-переміщеними особами), або міжнародно-правовий захист від інших держав. В останньому випадку, вони отримують статус біженця за Конвенцією про статус біженців 1951 року [2], або набувають інших форм захисту від інших держав. На приклад, Законом України «Про біженців та осіб, які потребують додаткового або тимчасового захисту» [3] передбачено таку категорію осіб як особи, що отримали додатковий захист, та особи, які отримали тимчасовий захист. Ці особи не є біженцями 3 точку зору міжнародно-правових зобов'язань України за Конвенцією про статус біженців, однак користуються захистом України в силу ії зобов’язань за міжнародним правом прав людини.

Розвиток подій в Україні в останні роки створив складну ситуацію для біженців. 3 одного боку, Україна сама перетворилася на країну походження біженців через триваючий збройний конфлікт, окупацію частини території. Безумовно, альтернатива внутрішнього переміщення розглядається як основна державами з розвинутою практикою надання статусу біженця, тобто українським громадянам, які втікають з зони конфлікту, не варто розраховувати на статус біженця в інших державах, оскільки більша частина України лишається мирною, а отже ці особи можуть почати нове життя в іншій частині держави. Однак, це не виключає надання окремим українським громадянам статусу біженця в іншій країні через їхню індивідуальну ситуацію.

3 іншого боку, надання Україні безвізового режиму з СС та наявність довжелезного погано контрольованого кордону, а також межування України одразу з двома невизнаними територіями (так звані

\footnotetext{
1 Автор віддає перевагу терміну «транзитивна юстиція», однак для цілей цієї роботи послуговуватиметься загальновизнаним визначенням. Докладніше див: [1, с. 43].
}

УДК 341.3 плОтнІков Олексій Вікторович

кандидат юридичних наук, професор,

() О. Плотніков, 2019

Старший юрист ГО «Десяте Квітня» 
«ЛДНР» та так звана «Придністровська молдавська республіка») перетворюють Україну на ідеальну транзитну країну для людського трафіку через Російську Федерацію до Європейського Союзу. При цьому, Україна відіграє роль «буферу» ЄС на шляху людського потоку, що прямує з Афганістану, Іраку, Сирії та інших країн. Для багатьох осіб, що прагнуть нелегально потрапити до СС, шлях обривається саме в Україні. В разі затримання, такі особи часто не мають іншої перспективи, крім як звернутися за міжнародним захистом в Україні. Чимало з них мають для цього правові підстави. Варто додати також, що для багатьох осіб, особливо з країн колишнього СРСР, і сама Україна виглядає як приваблива країна для звернення за міжнародним захистом.

Як наслідок, в Україні зростає кількість осіб, які можуть отримати чи вже отримали статус біженця. За даними Державної міграційної служби України [4], лише за перші чотири місяці 2019 року за міжнародним захистом в Україні звернулося 194 особи. Загальна ж кількість осіб, які визнані біженцями, складає 1799 осіб, а осіб, які отримали додатковий захист - 768 осіб. Крім того, на розгляді органів Державної міграційної служби перебуває близько 400 заяв про звернення за захистом в Україні, і кількість таких заяв, імовірно, зростатиме, адже безпекова ситуація в основних країнах походження біженців (Афганістан, Бангладеш, Росія, Сирія) не покращується. Водночас, значною мірою через тиск Європейського Союзу, Україна приймає все більш жорстких заходів для боротьби 3 нелегальною міграцією через свою територію до країн СС. Як наслідок, в Україні затримується все більше осіб, які прямували до СС, і природно, що ці особи намагаються отримати в Україні статус біженця. Деякі з них дійсно мають для цього підстави.

Може здатися, що кількість біженців в Україні є невеликою, порівняно з кількістю внутрішньо переміщених осіб. Однак, тут слід брати до уваги два моменти. По-перше, міжнародна спільнота, зокрема ООН, приділяє велику увагу захисту прав біженців як вразливої категорії осіб, які не мають захисту держави свого походження та змушені сподіватися на захист інших держав. По-друге, особи, що є біженцями, мають додатковий захист, або шукають притулку в Україні, також страждають від наслідків збройного конфлікту та окупації, стаючи одночасно біженцями та внутрішньо переміщеними особами в Україні.

Показовою є розглянуті Львівським окружним адміністративним судом справи [5] [6] членів організації «Хізб ут-Тахрір» походженням з Російської Федерації, які, через переслідування в Росії, які, оселившись в Автономній Республіці Крим, звернулися з заявою про надання міжнародного захисту в Україні. Станом на початок 2014 року, щодо них тривала процедура надання такого статусу. Однак, з початком агресії проти України та окупацією Автономної Республіки Крим, ці особи змушені були втекти до неокупованої частини України та там повторно звернулися за статусом біженця. Таким чином, з точки зору українського законодавства, такі особи є одночасно і біженцями і внутрішньо переміщеними особами. Вони та інші особи в аналогічних обставинах потребують окремої уваги при формуванні державної політики в галузі правосуддя перехідного періоду через те, що ці особи є жертвами одночасно двох конфліктних ситуацій.

Те, що біженці з інших країн, які перебувають в державі, в якій відбувається ситуація конфлікту чи переходу, повинні розглядатися як окрема група акторів для цілей застосування механізму правосуддя перехідного періоду, не є новиною. Відомо чимало випадків коли новий конфлікт або транзит зачіпали мешканців, які самі є біженцями від попереднього конфлікту. Можна згадати спільноти палестинських біженців в Сирії, або суданських біженців в Еритреї, представники яких мешкають на території України та теж стикаються з наслідками конфліктної ситуації в нашій державі.

Проблематика біженців окремо розглядалася комісіями правди в Ліберії, Гані, Нігерії та СьєрраЛеоне [7]. С. Вольфсон, старший радник з правових питань Агентства ООН у справах біженців, підкреслює, що потрапляння біженців до нової конфліктної ситуації поглиблює їхню і без того велику соціальну ізоляцію та сприяє розколу спільноти, до якої біженці намагаються приєднатися. Наявність в спільноті, яка переживає конфлікт, біженців підвищує ії конфліктний потенціал [8, p. 55]. Отже, біженці неодмінно мають розглядатися як актори транзитивного процесу, який має слугувати, в тому числі, їхнім інтересам, а через них інтересам всієї спільноти.

Проблема забезпечення прав біженців в конфлікті та постконфліктному врегулювання в Україні, в принципі, відома. Можна згадати положення Закону «Про забезпечення прав і свобод громадян та правовий режим на тимчасово окупованій території», яким встановлюється порядок реєстрації біженців при їхньому виїзді з окупованої території на неокуповану та підкреслюється збереження за ними певних прав, зокрема права на власність, на працевлаштування та на освіту [9]. Питання щодо біженців в аспекті правосуддя перехідного періоду піднімають неурядові організації (на приклад, див. [9]. Однак, це питання потребує не окремих згадок, а комплексного наукового дослідження 3 метою подальшого врахування в ході розробки та впровадження в Україні стратегії правосуддя перехідного періоду. 
1. Плотніков О.В. Правосуддя перехідного періоду чи транзитивна юстиція: до питання про визначення терміну. Український часопис міжнародного права. 2016. № 4. С. 43-47.

2. Конвенція про статус біженців від 28.07.1951.

3. Про біженців та осіб, які потребують додаткового або тимчасового захисту. Закон України від 08.07.2011 № 3671-VI.

4. Офіційний сайт Державної міграційної служби України. URL: https:/ /dmsu.gov.ua/diyalnist/ statistichni-dani/shhotizhnevi-pokazniki-diyalnosti.html (Дата звернення: 30.05.3019).

5. Постанова Львівського окружного адміністративного суду від 05.01.2015 у справі № 813/5453/14. URL: http://www.reyestr.court.gov.ua/Review/42338734 (Дата звернення: 01.06.3019).

6. Постанова Львівського окружного адміністративного суду від 04.02.2015 у справі № 813/5451/14. URL: http:/ / www.reyestr.court.gov.ua/Review/42612080 (Дата звернення: 01.06.3019);

7. Rimmer S.H. Reconceiving Refugees and Internally Displaced Persons as Transitional Justice Actors. New Issues in Refugee Research. Research Paper No 187. 2010. URL: https://www.refworld.org/ docid/4caae3f22.html (Accessed 01.06.2019).

8. Wolfson S. Refugees and Transitional Justice. Refugee Survey Quarterly. 2005. Vol. 24. P. 55-59.

9. Про забезпечення прав і свобод громадян та правовий режим на тимчасово окупованій території. Закон України від 15.04.2014 № 1207-VII.

10. Спільне звернення УВКБ ООН, БФ «Право на захист», ГО «Крим СОС», БФ «Восток-СОС» та Данської ради з питань біженців щодо проекту закону «Про тимчасово окуповану територію України». URL: http://vpl.com.ua/uk/news/spilne-zvernennya-uvkb-oon-bf-pravo-na-zakhyst-hokrym-sos-bf-vostok-sos-ta-danskoyi-rady-z-pytan-bizhentsiv-shchodo-proektu-zakonu-pro-tymchasovo-okupovanu-terytoriyu-ukrayiny (Accessed 01.06.2019).

\section{Summary}

The concept of transitional justice has gained widespread recognition in Ukraine after the start of Russia's armed aggression in 2014. After the international scientific conference "Post-Conflict Justice in Ukraine" held in May 2017, we can speak of a consensus among researchers and practitioners on the need for transitional justice in Ukraine. The scientific debate continues solely on its scope and forms. Transition justice can be defined as a set of judicial and non-judicial mechanisms that initiate a process of confrontation with the past of society with the inheritance of mass human rights violations. The idea of reconciliation was the basis for all transitional justice, and the goals laid down in its main mechanisms were based on the judgment of the Velásquez Rodríguez v. Honduras, 1988, namely: to use measures to prevent human rights violations, to carry out a serious investigation of the committed offenses, to identify both the victims and those responsible for the offense; to ensure that those responsible for the offense are properly punished and that victims of crime are compensated.

It is known that transitional justice is applicable in conflict and post-conflict situations. These situations are related to violence and gross human rights abuses. The natural consequence of such situations is the emergence of a large number of people seeking a resolution to the conflict or a situation of violence outside their place of residence in their own country or outside their own country. These persons may receive protection either from their state (then they become internally displaced persons) or international legal protection from other states. In the latter case, they obtain refugee status under the 1951 Refugee Convention or obtain other forms of protection from other States. For example, the Law of Ukraine "On Refugees and Persons in Need of Additional or Temporary Protection" provides for such a category of persons as persons who received additional protection and persons who received temporary protection. These persons are not refugees from the point of view of Ukraine's international legal obligations under the Refugee Convention, but they enjoy the protection of Ukraine by virtue of its obligations under international human rights law. The problem of ensuring the rights of refugees in conflict and post-conflict settlement in Ukraine is, in principle, well-known. Non-governmental organizations raise questions about refugees in the transitional justice dimension. However, this issue does not need to be mentioned individually, but rather a complex scientific study in order to further consider the development and implementation of a transitional justice strategy in Ukraine. 